\title{
KARAKTERISTIK ENERGI GELOMBANG DAN ARUS PERAIRAN DI PROVINSI MALUKU
}

\author{
Characteristic of Wave Energy and Current Velocity of Coastal Area at Maluku Province
}

\author{
GRACE LOUPATTY \\ Staf Jurusan Fisika FMIPA UNPATTI \\ Jl. Ir. M. Putuhena, Kampus Unpatti, Poka-Ambon, Maluku \\ e-mail: grace_loupatty@yahoo.com
}

\begin{abstract}
ABSTRAK
Beberapa wilayah di Provinsi Maluku memiliki bentuk topografi pantai yang dari waktu ke waktu mengalami perubahan terhadap struktur garis pantainya. Faktor utama yang turut berpengaruh adalah profil pola gelombang laut dan pola arus permukaan pada pesisir pantai.

Penelitian ini bertujuan untuk mengkarakterisasi serta menganalisis profil gelombang laut dan arus air laut pada tujuh lokasi pantai di Provinsi Maluku.

Dengan pengukuran periode gelombang $T$, tinggi gelombang $H$, maka dihitung panjang gelombang $L$ dan energi gelombang $E$. Kemudian dianalisis dengan menggunakan excel dan analisis klaster hirarkhi dengan program SPSS. Kecepatan arus dihitung dan dianalisis pada ketujuh lokasi pantai.

Hasil yang diperoleh pada ketujuh lokasi tersebut, dapat disimpulkan bahwa energi gelombang dan kecepatan arus di Teluk Baguala memiliki karakteristik yang berbeda terhadap enam lokasi pantai yang lain.
\end{abstract}

Kata Kunci : Karakteristik, energi gelombang, arus

\section{PENDAHULUAN}

Perairan Maluku tergolong memiliki wilayah perairan yang dalam dan dangkal. Pada kedua wilayah perairan tersebut secara alami terjadi proses pengadukan atau pencampuran air permukaan dengan air di bagian dasar karena adanya pengaruh gelombang, arus, angin dan pasang surut. Hal ini merupakan suatu proses fenomena alam yang biasanya terjadi pada suatu perairan. Proses alamiah yang terjadi pada perairan tersebut dapat dikaji lewat parameter oseanografi pantai yaitu gelombang, arus, angin, pasang surut dan transport sedimen.

Gelombang laut merupakan gerakan permukaan air laut akibat hembusan angin. Angin yang bertiup di atas permukaan air laut menimbulkan gelombang dan membawa suatu kecepatan yang mempunyai energi. Energi gelombang dapat dijadikan sebagai energi pengganti minyak atau energi terbarukan.

Penelitian ini bertujuan untuk mengkarakterisasi serta menganalisis profil gelombang laut dan arus air laut pada beberapa lokasi pantai di Provinsi Maluku.

\section{TINJAUAN PUSTAKA}

Perairan Maluku yang merupakan bagian dari perairan Indonesia Timur memiliki keadaan fisik yang unik. Perairan ini terdiri dari laut yang dalam dengan topografi dasar laut yang majemuk dan memiliki wilayah laut yang luas karena merupakan batas antara dua samudera, yaitu samudera Pasifik dan samudera Hindia. Disamping itu, perairan Maluku juga tergolong memiliki wilayah perairan yang dalam dan dangkal. Pada kedua wilayah perairan tersebut secara alami terjadi proses pengadukan atau pencampuran air permukaan dengan air di bagian dasar karena adanya pengaruh gelombang, arus, angin dan pasang surut. Hal ini merupakan suatu proses fenomena alam yang biasanya terjadi pada suatu perairan. Proses alamiah yang terjadi pada perairan tersebut dapat dikaji lewat parameter oseanografi pantai seperti gelombang dan arus.

\section{Gelombang Laut}

Gelombang laut merupakan suatu fenomena alam berupa penaikan dan penurunan air secara perlahan dan dapat 
dijumpai di seluruh dunia. Gelombang yang berada di laut sering nampak tidak teratur dan sering berubah-ubah. Hal ini bisa diamati dari permukaan airnya yang diakibatkan oleh arah perambatan gelombang yang sangat bervariasi serta bentuk gelombangnya yang tidak beraturan, apalagi jika gelombang tersebut dibawah pengaruh angin.

Angin yang berhembus di atas permukaan air yang semula tenang akan menyebabkan gangguan pada permukaan tersebut, selanjutnya timbul riak-riak gelombang kecil di atas permukaan air. Angin yang bertiup di permukaan laut ini merupakan pembangkit utama gelombang. Apabila kecepatan angin bertambah, riak gelombang tersebut menjadi bertambah besar dan jika angin berhembus terus-menerus akhirnya terbentuk gelombang. Disamping itu, pergerakan massa air yang ditimbulkan oleh angin dapat menghasilkan momentum dan energi sehingga gelombang yang dihasilkan tidak menentu.

Pratikto (2000) mengatakan bahwa bentuk dan perambatan gelombang yang bervariasi serta tidak beraturan sangat mempengaruhi karakteristik gelombang yang terjadi pada perairan tersebut. Selain terjadi perubahan tinggi, panjang dan kecepatan gelombang juga terjadi fenomena lain seperti pendangkalan, refraksi, difraksi dan pantulan sebelum gelombang tersebut pecah. Pendangkalan gelombang adalah proses berkurangnya tinggi gelombang akibat perubahan kedalaman dimana kecepatan gelombangnya berkurang dan akibatnya juga terjadi refraksi karena arah gerak puncak gelombang mengikuti bentuk kontur kedalaman laut. Refraksi ditekankan pada perubahan tinggi gelombang karena pembelokan arah puncak gelombang. Sedangkan difraksi adalah proses pemindahan ke arah daerah yang terlindungi sehingga menyebabkan timbulnya gelombang.

Menurut Tarigan (1986) gelombang laut merupakan gejala alam yang menimbulkan ayunan tinggi dan rendahnya massa air yang bergerak tanpa hentinya pada lapisan permukaan maupun di bawah permukaan laut. Susunan gelombang di laut baik bentuknya maupun macamnya sangat bervariasi dan kompleks sehingga hampir tidak dapat diuraikan dan sulit digambarkan secara sistematis karena tidak linieran, tiga dimensi dan mempunyai bentuk yang random. Bentuk gelombang yang dihasilkan cenderung tidak menentu dan tergantung pada beberapa sifat gelombang seperti periode dan tinggi gelombang yang dibentuk (Triadmojo, 1999).

Gelombang didefenisikan sebagai ombak yang besar-besar ditengah lautan (Badudu dan Zain,2001). Gelombang laut merupakan salah satu penyebab yang berperan dalam pembentukan maupun perubahan bentuk pantai (Dahuri, 1987). Jika gelombang menjalar dari tempat yang dalam menuju ke tempat yang makin lama makin dangkal, pada suatu tempat tertentu gelombang tersebut akan pecah dan dilepaskan ke pantai dalam bentuk hempasan ombak.

Panjang gelombang dapat dihitung dengan persamaan (Souisa,2002):

dimana:

$$
L=\frac{g T^{2}}{2 \pi}=1.56 T^{2}
$$

$\mathrm{T}=$ periode ombak (detik)

$\mathrm{g}=$ Percepatan gravitasi $=9,81 \mathrm{~m} / \mathrm{s}^{2}$

$\mathrm{L}=$ Panjang gelombang $(\mathrm{m})$
Selanjutnya apabila dihitung periode ombak signifikan $\mathrm{H}_{\mathrm{S}}$, dan tinggi ombak signifikan didapat dari tinggi rerata dari $33 \%$ tinggi nilai pencatatan gelombang. Hal yang sama juga dapat digunakan untuk menghitung periode ombak.

Energi total gelombang adalah jumlah energi kinetik dan energi potensial. Energi kinetik adalah energi yang disebabkan oleh kecepatan partikel air karena adanya gerak gelombang sedangkan energi potensial adalah energi yang dihasilkan oleh perpindahan muka air karena adanya gelombang (Triadmodjo, 1996). Energi gelombang berubah dari satu titik ke titik yang lain sepanjang satu panjang gelombang, $L$, dan energi rerata dihitung dengan persamaan:

$$
E=\frac{1}{8} g \rho_{0} H^{2} \mathrm{~L}
$$

dimana:

$\rho_{0}=$ rapat massa, $\left(\mathrm{kg} / \mathrm{m}^{2}\right)$

$\mathrm{H}=$ tinggi gelombang, $(\mathrm{m})$

$\mathrm{L}=$ panjang gelombang, $(\mathrm{m})$

$\mathrm{E}=$ energi, $(\mathrm{J})$

\section{Arus}

Arus merupakan gerakan air yang sangat luas yang sering terjadi pada seluruh lautan. Gelombang yang datang menuju pantai dapat menimbulkan arus pantai (nearshore current). Arus juga dapat terbentuk akibat oleh angin yang bertiup dalam selang waktu yang sangat lama, dapat juga disebabkan oleh ombak yang membentur pantai secara miring. Dapat pula disebabkan oleh gelombang yang terbentuk dari gelombang yang datang menuju garis pantai. Dengan demikian akan terjadi dua system arus yang mendominasi pergerakan air laut yaitu arus meretas pantai (rip current) dan arus sejajar pantai atau arus susur pantai (longshore current).

Arus dapat juga membawa sedimen yang mengapung (suspended sediment) maupun yang terdapat didasar laut. Begitu pula dengan arus susur pantai dan arus meretas pantai. Keduanya merupakan arus yang berperan dalam transport sedimen di sepanjang pantai serta pembentukan berbagai sedimen yang terdapat di pantai.

\section{METODE PENELITIAN}

\section{Lokasi Penelitian}

a. Pulau Ambon:

Pantai Teluk Ambon Dalam,Pantai Teluk Ambon Luar, Pantai Teluk Baguala

b. Pulau Seram Bagian Barat:

Pantai Kamariang, Pantai Kairatu, Pantai Waisarisa, Pantai Piru

\section{Peralatan}

Peralatan yang digunakan :

a. GPS, Kompas

b. Rambu gelombang (palm), Current cross

c. Stopwatch/timer

d. Meter rol (50m)

e. Speed boat/perahu

f. Kamera

g. Busur derajat, Alat tulis 


\section{Prosedur Penelitian}

i. Parameter Gelombang ( tinggi gelombang, periode gelombang dan kedalaman air/ pasang-surut)

Prosedur kerja:

1. Rambu gelombang (palm) dipasang pada daerah breaker zone saat air surut, setelah terpasang maka ditentukan titik 0 (sebagai titik awal), kemudian pengamatan dilakukan dengan cara:

a. Pengukuran periode gelombang $T$, sebanyak $\mathrm{N}$ kali dalam waktu 30 menit.

b. Pengukuran tinggi gelombang $H$,

c. Pengukuran sudut datang gelombang terhadap garis pantai setiap 30 menit.

2. Pengambilan data dilakukan selama waktu diatas untuk menentukan energi gelombang

\section{ii. Kecepatan Arus}

Prosedur kerja:

Dengan menggunakan speedboad/perahu, pengukuran dimulai pada stasiun 1 (jarak pengambilan stasiun diambil berdasarkan panjang garis pantai pengamatan). Diulangi 3 kali dan hasil akhir diambil reratanya. Setelah itu berpindah ke stasiun $2,3, \ldots, 7$.

Pengukuran kecepatan arus dilakukan pada hari pertama sampai hari ke-enam .

\section{Analisis Data}

Hasil pengukuran periode gelombang $T$ dan tinggi gelombang $H$, dihitung panjang gelombang $L$ dengan persamaan (1). Kemudian energi gelombang $E$ dihitung dengan menggunakan persamaan (2).

Hasil pengamatan yang diperoleh dianalisis dengan menggunakan excel dan analisis klaster hirarkhi menggunakan program SPSS.

Kecepatan arus dihitung dan dianalisis pada ketujuh lokasi perairan.

\section{HASIL DAN PEMBAHASAN}

\section{Gelombang dan Kecepatan Arus}

Untuk menghitung energi gelombang maka data parameter gelombang ditabulasikan untuk 7 stasiun dengan variabel $\mathrm{X} 1-\mathrm{X} 3$, dihitung reratanya dengan menggunakan excel. Kecepatan arus, di tabulasikan untuk 7 stasiun dengan variabel $\mathrm{X} 4-\mathrm{X} 6$, dihitung reratanya juga dengan menggunakan excel:

$$
\begin{aligned}
& X 1 \text { = rerata energi pada pagi hari } \\
& X 2 \text { = rerata energi pada siang hari } \\
& X 3 \text { = rerata energi pada sore hari } \\
& X 4=\text { rerata kecepatan arus pada pagi hari } \\
& \text { X5 = rerata kecepatan arus pada siang hari } \\
& \text { X6 = rerata kecepatan arus pada sore hari }
\end{aligned}
$$

Tabel 1. Rerata Energi dan Rerata kecepatan arus

\begin{tabular}{|c|l|r|r|r|c|c|c|}
\hline No & Pantai & \multicolumn{1}{|c|}{$\mathbf{X 1}$} & \multicolumn{1}{|c|}{$\mathbf{2}$} & \multicolumn{1}{|c|}{$\mathbf{X 3}$} & $\mathbf{X 4}$ & $\mathbf{X 5}$ & $\mathbf{X 6}$ \\
\hline 2 & TAL & 562.06 & 806.31 & 620.36 & 0.22 & 0.22 & 0.24 \\
\hline 3 & TBG & 37.53 & 2.39 & 0.61 & 0.21 & 0.19 & 0.22 \\
\hline 4 & KAMA & 287.64 & 470.22 & 579.66 & 0.40 & 0.46 & 0.49 \\
\hline 6 & WAI & 108.75 & 202.74 & 238.93 & 0.23 & 0.25 & 0.26 \\
\hline 7 & PIR & 69.48 & 108.77 & 271.12 & 0.40 & 0.46 & 0.49 \\
\hline 1 & TAD & 392.54 & 1220.15 & 1488.35 & 0.32 & 0.34 & 0.33 \\
\hline 5 & KAI & 520.10 & 1723.94 & 2503.82 & 0.17 & 0.33 & 0.35 \\
\hline
\end{tabular}

Setelah dilakukan analisis data menggunakan analisis cluster hierarkhi dengan menggunakan program SPSS, diperoleh hasil sebagai berikut:

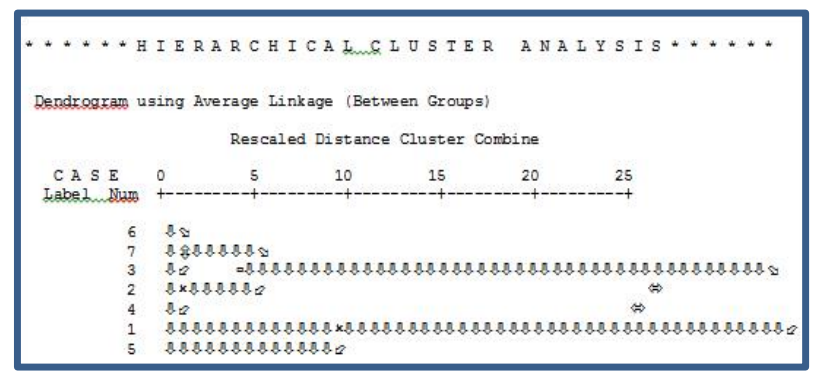

Gambar 1. Analisis hirarki energi gelombang dan kecepatan arus

Dari analisis diperoleh 2 kelas.

Kelas $I=$ Teluk 3 yaitu Pantai teluk Baguala,

Kelas II $=$ Teluk 1 (Pantai Teluk Ambon Dalam), 2 (Pantai Teluk Ambon Luar), 4 (Pantai Kamariang), 5 (Pantai Kairatu), 6 (Pantai Waisarisa), dan 7 (Pantai Piru).

Teluk Baguala mempunyai nilai energi gelombang dan kecepatan arus yang berbeda dengan pantai yang lain. Nilai energi gelombang dan kecepatan arus di Pantai Kamariang mempunyai kemiripan dengan nilai energi gelombang dan kecepatan arus di Teluk Ambon Dalam,di Pantai Waisarisa dan Pantai Kairatu, juga mirip dengan di Pantai Piru dan Teluk Ambon Luar.

Energi gelombang berpengaruh terhadap morfologi pantai khususnya abrasi dan rekresi.

Abrasi merupakan proses pengikisan oleh energi gelombang laut dan arus laut yang bersifat merusak atau pengangkutan tanah yang tebalnya sama, terjadi di suatu permukaan tanah. Rekresi merupakan kenampakan pembentukan pantai yang maju ke arah laut berupa hadirnya daratan yang baru.

Parameter-paramater gelombang dan pola sirkulasi air laut pada daerah pantai merupakan faktor kajian yang utama karena erat kaitannya dengan proses perubahan morfologi pantai yaitu proses pengikisan (abrasi pantai) dan proses pembentukan (rekresi). Besarnya proses tersebut bergantung pada besarnya energi yang dihempaskan oleh gelombang ke pantai.

Dengan informasi parameter gelombang yang ada, jika dilakukan perhitungan dengan persamaan normalisasi CERC, maka dapat diketahui pantai mengalami abrasi, rekresi, atau pantai dalam keadaan kesetimbangan ( tidak terjadi abrasi maupun rekresi). 


\section{KESIMPULAN}

\section{Kesimpulan}

Berdasarkan hasil perhitungan dan analisis pada ketujuh lokasi tersebut, dapat disimpulkan bahwa energi gelombang dan kecepatan arus di Teluk Baguala memiliki karakteristik yang berbeda terhadap keenam lokasi pantai yang lain.

\section{Saran}

Sebaiknya dilakukan penelitian yang sama pada lokasi lain di Provinsi Maluku, agar dapat diperoleh informasi yang lebih lengkap tentang parameter oseanografi dan dapat dibuat pemetaan gugus pulau berdasarkan potensi wilayah kepulauan.

\section{DAFTAR PUSTAKA}

Badudu dan Zain, 2001. Kamus Besar Bahasa Indonesia. Balai Pustaka, Jakarta.

Dahuri, R., 1987. Pengelolaan Sumber Daya Wilayah Pesisir dan Lautan Secara Terpadu. Pradya Paramita, Jakarta.

Pratikto, W.A. dkk, 2000. Struktur Pelindung Pantai, hibah Pengajaran - Like. Teknik Kelautan, Institut Teknologi Sepuluh Nopember, Surabaya.

Souisa, M., 2002. Fisika Kelautan, Jurusan Fisika Universitas Pattimura, Ambon.

Tarigan, M. S., 1986. Studi Pendahuluan Energi Gelombang di Teluk Ambon Bagian Luar. Puslitbang Oseanologi-LIPI, Ambon

Triadmodjo, B., 1996. Pelabuhan. Beta Offset, Yogyakarta.

Triadmodjo, B., 1999. Teknik Pantai. Beta Offset, Yogyakarta. 